\title{
Physicochemical properties and antioxidant activities of hot water extracts from medicinal fruit mixture
}

\author{
Yul-Ri Gu${ }^{1}$, Hye-Mi Park ${ }^{1}$, Yoo Seok Jeong ${ }^{2}$, Hee Kyoung Jung ${ }^{2}$, \\ Jeong Hyun Yun ${ }^{3}$, Joo-Heon Hong ${ }^{1 *}$ \\ ${ }^{1}$ Department of Food Science and Technology, Catholic University of Daegu, Gyeongsan 38430, Korea \\ ${ }^{2}$ Biohealth Convergence Center, Daegu Technopark, Daegu 41256, Korea \\ ${ }^{3}$ Pro-M Co., Daegu 42716, Korea
}

\section{약용열매 혼합 열수 추출물의 이화학적 특성 및 항산화 활성}

\author{
구율리 ${ }^{1} \cdot$ 박혜미 $^{1} \cdot$ 정유석 ${ }^{2} \cdot$ 정희경 ${ }^{2} \cdot$ 윤정현 $^{3} \cdot$ 홍주헌 $^{1 *}$ \\ ${ }^{1}$ 대구가톨릭대학교 식품공학전공, ${ }^{2}($ 재 $)$ 대구테크노파크 바이오헬스융합센터, ${ }^{3}$ 프로엠
}

\begin{abstract}
This study was conducted to examine the physicochemical properties and antioxidant activities of medicinal fruit extracts (Corni fructus, Schizandra chinensis, Rubus coreanus Miquel and Lycii folium) with different extraction mixing ratios (MS, an equal ratio of the medicinal fruit = 1.25:1.25:1.25:1.25; M1, 2:1:1:1; M2, 1:2:1:1; M3, 1:1:2:1 and M4, 1:1:1:2) from medicinal fruit. $\mathrm{pH}$, sugar content and acidity of the extracts were 3.22 3.52, 3.20 4.20 ${ }^{\circ}$ Brix and 3.60 5.85\%, respectively. The extraction yield of M2 (42.33\%) was higher than those of MS $(36.03 \%)$, M1 (40.40\%), M3 (32.53\%) and M4 (35.90\%). The total polyphenol and flavonoid contents of M3 were 14.54 $\mathrm{g} / 100 \mathrm{~g}$ and $5.65 \mathrm{~g} / 100 \mathrm{~g}$, respectively. The DPPH and ABTS radical scavenging activities of $\mathrm{M3}$ at $1,000 \mu \mathrm{g} / \mathrm{mL}$ were $86.09 \%$ and $90.49 \%$, respectively. The ferric-reducing antioxidant power and the reducing power of $\mathrm{M3}$ at $250 \sim 1,000 \mu \mathrm{g} / \mathrm{mL}$ were $0.36 \sim 0.86 \mu \mathrm{M}$ and $0.21 \sim 0.96$, respectively. The antioxidant activities of $\mathrm{M3}$ were significantly higher than those of the other extracts. In conclusion, this study demonstrated that medicinal fruit extracts had potential as a functional material.
\end{abstract}

Key words : Corni fructus, Schizandra chinensis, Rubus coreanus Miquel, Lycii folium, antioxidant activities

\section{서 론}

생약이나 약용식물은 동양의학과 민간에서 치료 및 예방 의 목적으로 사용되어 왔으며, 또한 생약재의 2 차 대사산물 이 생체에 대한 생리활성 효과를 이용한 천연소재로서 연구 가 이루어지고 있다(1-3). 이러한 점에서 생약이나 약용식 물은 기능성식품의 소재 분야에 광범위하게 활용이 기대되 므로, 항산화 활성이 높고 인체에 무해한 성분을 찾으려는

*Corresponding author. E-mail : jhhong@cu.ac.kr Phone : 82-53-850-3218, Fax : 82-53-850-3218

Received 15 January 2016; Revised 2 February 2016; Accepted 3 February 2016.

Copyright (c) The Korean Society of Food Preservation. All rights reserved.
시도가 활발히 진행되고 있다(4). 생약이나 약용식물은 낮 은 독성과 부작용으로 인하여 우리나라와 동양권에서 민간 요법으로 오랫동안 이용되어 왔고(5), 통증완화, 항염증, 방부, 해열, 해독 및 수렴 등의 다양한 생리활성 효능이 있다(6). 그 중에서 ‘동의보감’의 과실편 등에 소개되는 열 매와 그 열매가 있는 나무를 이용하는 수많은 약재 중에 현재 가장 친숙한 산수유, 오미자, 복분자 및 구기자는 약용 열매 4대 천왕이라 알려져 있는데, 2011년 기준 약용식물 총 생산액은 14,498 억 원 중 복분자가 3,864 억 원, 오미자가 3,178 억 원으로 전체 약용식물의 $48.50 \%$ 를 차지할 정도의 거대 약용식물 자원이며, 한약재로서 뿐만 아니라 소비자 들에게도 친숙한 생물자원이다(7). 이들의 성분인 비타민 $\mathrm{C}$, 카로티노이드, 식이섬유, 페놀 화합물 및 플라보노이드 등은 항종양활성, 항암활성, 콜레스테롤 저하작용, 항산화 
성 및 정장작용 등 다양한 생리적 기능을 나타내고 있다(8). 산수유(Corni fructus)는 층층나무과에 속하는 산수유나 무(Cornus officinalis)의 과육으로, 가을에 성숙한 붉은색 열매의 씨를 제거한 건조한 과육을 산수유라 하며(9), 예로 부터 우리나라를 비롯하여 중국과 일본 등에서 중요한 한약 재로 많이 사용되어 왔다(10). 산수유는 그 맛이 시고 성질 은 따뜻하고, 다뇨증, 요통, 이명 및 폐결핵 등의 치료제로 사용되어 왔다. 그 과실은 자양, 강장, 음위 및 이조에 약효 가 있으며, 간경화와 신경에 좋고, 이뇨작용, 혈압강하작용, 항암 및 항균 작용 등의 약리작용이 있다고 한방자료에 기록되어 있다(11). 오미자(Schizandra chinensis)는 목련과 (Magnoliaceae)로 단맛, 신맛, 쓴맛, 매운맛 및 짠맛의 다섯 가지 맛이 어우러진 독특한 풍미를 가진 열매이며, 안토시 아닌에 의한 선명한 붉은색을 나타내는 것이 특징이다. 오 미자는 알코올 해독 작용 및 항산화 작용이 뛰어나다고 보고되어 있으며(12), 안토시아닌, 플라보노이드 및 유기산 류 등이 풍부하여 예로부터 한방에서는 거담, 자양 및 강장 제 등으로 이용되었고 간장 보호, 혈당 강하, 콜레스테롤 저하, 고지혈증 완화, 면역 조절, 항암 및 항종양 등 다양한 생리적 활성이 있는 것으로 알려져 있다(13). 복분자(Rubus coreanus Miquel)는 장미과(Rosaceae), 산딸기속(rubus)으 로 주로 한국, 중국 및 일본 등의 아시아에 많이 분포하고, 열매는 6 7월경에 적색으로 익은 후 나중에는 검게 변한다. 복분자에는 여러 가지 유기산과 비타민류, 여러 가지 무기 성분 및 탄닌을 포함한 플라보노이드류 성분이 풍부한 것으 로 알려져 있으며, 항암활성, 면역증진효과, 항산화효과 항 균효과, anaphylaxis 억제효과, 혈관신생억제(anti-angiogenesis) 효과, 알레르기 관련 질병에 치료효과 및 고지혈증 효과 등 다양한 생리활성이 있는 것으로 보고되어 있다(14-16). 구기자 나무(Lycium chinense Miller)는 가지과(Solanaceae) 에 속하는 덩굴성 관목으로 우리나라를 비롯하여 중국, 대 만 및 일본 등지에서 재배 및 자생하고 있다. 열매인 구기자 (Lycii folium), 뿌리인 지골피(Lycii cortex), 그리고 구기엽 (Lycii folium) 등은 콩팥과 간을 보호하고 눈을 밝게 하며, 근육과 빼를 튼튼하게 하여 관절염 등을 치료 및 갈증을 멈추게 하는 효능이 있다고 알려져 있다(17).

본 연구에서는 다양한 생리활성이 있다고 알려져 있는 약용열매인 산수유, 오미자, 복분자 및 구기자 4 종을 선정 하여 기능성식품 소재로 활용하고자, 혼합비율별로 열수 추출물을 제조하였으며 추출물의 이화학적 특성 및 항산화 활성을 조사하였다.

\section{재료 및 방법}

\section{실험재료}

본 실험에 사용된 산수유는 경상북도 의성군, 오미자는
경상북도 문경시, 복분자는 경상남도 하동군 및 구기자는 충청남도 청양군에서 재배되어 건조된 것을 2015년 7월 경상북도 경산시 소재의 농협 하나로 마트에서 구입하여 사용하였으며, 구입한 약용열매 4종은 냉장 보관하였다.

\section{추출물의 제조}

약용열매 4종을 건식분쇄기(FM-909W, Hami Co., Sejong, Korea)로 각각 분쇄한 다음 표준망체 $60 \mathrm{mesh}$, Chung Gye Sang Cong Sa, Seoul, Korea)를 통과시킨 분말을 Table 1 과 같이 비율별로 혼합한 시료 $40 \mathrm{~g}$ 에 10 배의 증류수 를 첨가하였다. $100^{\circ} \mathrm{C}$ 에서 3 시간 동안 환류냉각추출기 (CA-1112, Eyela Co., Japan)를 이용하여 추출하였고 각각의 추출물은 불순물을 제거하기 위하여 여과지(No.2, Whatman Intemational Ltd, Leicestershire, England)를 이용하여 여과 하였다. 여과된 용액은 감압농축기(Model N-1N, Eyela Co., Tokyo, Japan)로 농축한 다음, 동결건조기(Free Zone 2.5, Labconco Co., Kansas, MO, USA)로 건조하여 $-70^{\circ} \mathrm{C}$ 이하의 암소에 보관하면서 시료로 사용하였다.

Table 1. Mixture ratios of Corni fructus, Schizandra chinensis, Rubus coreanus Miquel, and Lycii folium

\begin{tabular}{ccccc}
\hline Sample $^{1)}$ & Corni fructus & $\begin{array}{c}\text { Schizandra } \\
\text { chinensis }\end{array}$ & $\begin{array}{c}\text { Rubus coreanus } \\
\text { Miquel }\end{array}$ & Lycii folium \\
\hline MS & 1.25 & 1.25 & 1.25 & 1.25 \\
M1 & 2 & 1 & 1 & 1 \\
M2 & 1 & 2 & 1 & 1 \\
M3 & 1 & 1 & 2 & 1 \\
M4 & 1 & 1 & 1 & 2 \\
\hline
\end{tabular}

${ }^{1)} \mathrm{MS}$, A mixture of same ratio (Corni fructus : Schizandra chinensis : Rubus coreanus Miquel : Lycii folium $=1.25: 1.25: 1.25: 1.25)$; M1, A mixture of different ratio (Corni fructus : Schizandra chinensis : Rubus coreanus Miquel : Lycii folium $=2: 1: 1: 1)$; M2, A mixture of different ratio (Corni fructus : Schizandra chinensis : Rubus coreanus Miquel: Lycii folium $=1: 2: 1: 1)$; M3, A mixture of different ratio (Corni fructus : Schizandra chinensis : Rubus coreanus Miquel Lycii folium $=1: 1: 2: 1$ ); M4, A mixture of different ratio (Corni fructus Schizandra chinensis : Rubus coreanus Miquel : Lycii folium =1:1:1:2).

\section{$\mathrm{pH}$, 당도 및 산도 측정}

각각의 약용열매 혼합 열수 추출물 동결건조분말 $1 \mathrm{~g}$ 에 20 배의 증류수를 첨가하여 이를 분석용 시료로 사용하였다. pH는 pH meter(CH 8603, Mettler-Toledo Inc., Schwarzenbach, Switzerland)를 이용하여 측정하였으며, 당도는 굴절당도계 (Master-a, Atage Co., Tokyo, Japan)를 이용하여 측정하였 다. 산도는 $\mathrm{pH}$ 가 8.3 이 되도록 각각의 시료 $1 \mathrm{~mL}$ 에 0.1 $\mathrm{N} \mathrm{NaOH}$ 를 적하하여 소비한 양을 lactic acid(0.009)로 환산 하여 계산하였다.

$$
\operatorname{Acidity}(\%)=\left(\frac{0.1 \mathrm{NNaOH} \text { 소비량 } \times 0.009 \times 100}{\text { 시료량 }}\right) \times \text { 희석배수 }
$$


추출수율, 총 폴리페놀 함량, 총 플라보노이드 함량 및 총 당 함량

약용열매 혼합 열수 추출물의 수율은 동결건조(Free Zone 2.5, Labconco Co.)한 다음 건물 중량을 구하였고 시료 조제에 사용한 원료 건물량에 대한 백분율로 나타내었다.

총 폴리페놀 함량은 Folin-Denis법(18)에 따라 시료 $1 \mathrm{~mL}$ 에 $1 \mathrm{~N}$ Folin ciocalteu reagent $1 \mathrm{~mL}$ 를 첨가하고 충분히 혼합한 다음 $20 \% \mathrm{Na}_{2} \mathrm{CO}_{3} 1 \mathrm{~mL}$ 를 첨가하여 실온의 암소에 서 30분간 반응시킨 후 분광광도계(Ultraspec 2100pro, Amersham Co., Uppsala, Sweden)를 이용하여 $725 \mathrm{~nm}$ 에서 흡광도를 측정하였다. 총 폴리페놀 함량은 Tannic acid (Sigma Co., St. Louis, MO, USA)를 정량하여 작성한 표준곡 선으로부터 계산하였다.

총 플라보노이드 함량은 $\mathrm{Jia}$ 등(19)의 방법을 응용하여 측정하였다. 시료 $1 \mathrm{~mL}$ 에 $5 \% \mathrm{NaNO}_{2} 150 \mu \mathrm{L}$ 를 혼합하여 실온에서 6 분간 반응 시킨 후 $10 \% \mathrm{AlCl}_{3} 300 \mu \mathrm{L}$ 와 혼합하여 다시 실온에서 5 분간 반응 시킨 후 $1 \mathrm{~N} \mathrm{NaOH} 1 \mathrm{~mL}$ 와 혼합한 후 분광광도계(Ultraspec 2100pro, Amersham Co., Uppsala, Sweden)를 이용하여 $510 \mathrm{~nm}$ 에서 흡광도를 측정하 였다. 총 플라보노이드함량은 Rutin(Sigma Co., St. Louis, MO, USA)을 정량하여 작성한 표준곡선으로부터 계산하였다.

총 당 함량은 phenol-sulfuric acid 방법을 응용하여 측정 하였다(20). 즉, 시료 $1 \mathrm{~mL}$ 에 $5 \%$ phenol $1 \mathrm{~mL}$ 와 진한 $\mathrm{H}_{2} \mathrm{SO}_{4}$ $5 \mathrm{~mL}$ 를 첨가하여 실온에서 20 분간 반응 시킨 후 분광광도 계(Ultraspec 2100pro, Amersham Co., Uppsala, Sweden)를 이용하여 $470 \mathrm{~nm}$ 에서 흡광도를 측정하였다.

\section{$\mathrm{DPPH}$ radical 소거활성 측정}

DPPH radical 소거활성은 1,1-diphenyl-2-picrylhydrazyl $(\mathrm{DPPH})$ 의 환원력을 이용하여 측정하였다(21). 즉, $\mathrm{DPPH}$ reagent는 DPPH $12 \mathrm{mg}$ 을 absolute ethanol $100 \mathrm{~mL}$ 에 용해한 후 증류수 $100 \mathrm{~mL}$ 첨가하여 흡광도를 $517 \mathrm{~nm}$ 에서 약 1.6 으 로 조정하여 제조하였다. 시료 $0.5 \mathrm{~mL}$ 에 DPPH reagent 5 $\mathrm{mL}$ 를 혼합하여 실온에서 15 분간 반응시킨 후 분광광도계 (Ultraspec 2100pro, Amersham Co., Uppsala, Sweden)로 흡 광도를 측정하고 아래와 같이 계산하였다.

$\mathrm{DPPH}$ radical 소거 활성 $(\%)=\left(1-\frac{S}{C}\right) \times 100$

S : absorbance of sample at $517 \mathrm{~nm}$

C : absorbance of control at $517 \mathrm{~nm}$

\section{ABTS radical 소거활성 측정}

ABTS(2,2'-azino-bis(3-ethylbenzothiazoline-6-sulfonic acid)) radical 소거활성(22)은 $7.4 \mathrm{mM} \mathrm{ABTS(Sigma-Aldrich}$ Co.)와 $2.45 \mathrm{mM}$ potassium persulfate를 최종 농도로 혼합하 여 실온인 암소에서 24시간 동안 방치하여 $\mathrm{ABTS}^{+}$을 형성
시킨 후 $732 \mathrm{~nm}$ 에서 흡광도 값이 $0.70 \pm 0.02$ 가 되게 phosphate buffer saline(PBS, pH 7.4)으로 희석하였다. 희석 된 용액 $180 \mu \mathrm{L}$ 에 시료 $20 \mu \mathrm{L}$ 를 혼합하여 정확히 1 분간 반응시킨 다음 분광광도계(Ultraspec 2100pro, Amersham Co., Uppsala, Sweden)를 이용하여 $732 \mathrm{~nm}$ 에서 흡광도를 측정하였다. ABTS radical 소거활성은 시료의 첨가 전과 후의 차이를 아래와 같이 백분율로 나타내었다.

ABTS radical 소거 활성 $(\%)=\left(1-\frac{S}{C}\right) \times 100$

S : absorbance of sample at $732 \mathrm{~nm}$

C : absorbance of control at $732 \mathrm{~nm}$

FRAP(ferric reducing antioxidant power) 측정

$\mathrm{FRAP}$ 는 Benzie와 Strain의 방법(23)에 따라 다음과 같이 측정하였다. FRAP reagent는 $25 \mathrm{~mL}$ acetate buffer $(300 \mathrm{mM}$, $\mathrm{pH} 3.6$ )를 $37^{\circ} \mathrm{C}$ 에서 가온한 후, $40 \mathrm{mM} \mathrm{HCl}$ 에 용해한 10 $\mathrm{mM}$ 2,4,6-tris(2-pyridyl)-S-triazine(TPTZ, Sigma, St, Louis, $\mathrm{MO}$, USA) $2.5 \mathrm{~mL}$ 와 $20 \mathrm{mM}$ ferric chloride( $\left.\mathrm{FeCl}_{3}\right) 2.5 \mathrm{~mL}$ 를 첨가하여 제조하였다. 시료 $30 \mu \mathrm{L}$ 에 제조된 FRAP reagent $900 \mu \mathrm{L}$ 와 증류수 $90 \mu \mathrm{L}$ 를 넣은 후 $37^{\circ} \mathrm{C}$ 에서 10 분간 반응시 킨 후 분광광도계(Ultraspec 2100pro, Amersham Co., Uppsala, Sweden)를 이용하여 $510 \mathrm{~nm}$ 에서 흡광도를 측정하 였다. FRAP는 $\mathrm{FeSO}_{4} \cdot 7 \mathrm{H}_{2} \mathrm{O}$ (Sigma Co., St. Louis, MO, USA) 을 정량하여 작성한 표준곡선으로부터 계산하였다.

\section{환원력 측정}

환원력은 $\mathrm{Oyaizu}$ 의 방법(24)에 따라 다음과 같이 측정하 였다. 시료 $1 \mathrm{~mL}$ 에 $0.2 \mathrm{M}$ phosphate buffer(pH 6.6) $2.5 \mathrm{~mL}$ 와 $1 \%$ potassium ferricyanide 용액 $2.5 \mathrm{~mL}$ 를 가한 후 $50^{\circ} \mathrm{C}$ 에서 30 분간 반응시켰다. 반응 후 $10 \%$ trichloroacetic acid 용액 $2.5 \mathrm{~mL}$ 를 가한 후 원심분리 한 뒤, 상등액 $2.5 \mathrm{~mL}$ 에 증류수 $2.5 \mathrm{~mL}$ 와 $0.1 \% \mathrm{FeCl}_{3}$ 용액 $0.5 \mathrm{~mL}$ 를 혼합한 다음 분광광도 계(Ultraspec 2100pro, Amersham Co., Uppsala, Sweden)를 이용하여 $700 \mathrm{~nm}$ 에서 흡광도를 측정하였다.

\section{통계처리}

모든 실험결과는 SPSS(version 19.0, SPSS Inc., Chicago, $\mathrm{IL}, \mathrm{USA})$ 를 이용한 분산분석(ANOVA)을 실시하였고 각 측정 평균값의 유의성 $(\mathrm{p}<0.05)$ 은 Duncan's multiple range test를 실시하여 검정하였다.

\section{결과 및 고찰}

$\mathrm{pH}$, 당도 및 산도 측정

약용열매 4 종의 혼합비율에 따른 열수 추출물의 $\mathrm{pH}$, 당 
도 및 산도의 결과는 Table 2 와 같다. 약용열매 혼합 열수 추출물의 $\mathrm{pH}$ 는 3.22 3.52의 범위로 오미자 혼합비율이 높 은 추출물에서 낮았으며, 추출물 간의 차이는 미미하였다. 당도는 MS, M1, M2 및 $\mathrm{M} 4$ 가 4.00 4.20 ${ }^{\circ} \mathrm{Brix}$ 로 유사하게 나타났으나, M3은 $3.20 \mathrm{Table}{ }^{\circ} \mathrm{Brix}$ 로 다른 추출물에 비해 낮게 나타났다. 복분자주 주박의 항균 항산화 및 항혈전활 성 연구에서 복분자는 그 자체로 우수한 식용가치를 가지고 있어 추출 음료 및 차 등의 식용으로 이용되고 있으나, 당도 가 낮고 신맛이 강해 생과보다는 설탕을 첨가한 과실주, 초콜릿 및 식빵 등의 가공식품으로 더욱 많이 이용되고 있다고 보고하였다(25). 산도는 3.60 5.85\%로 유의적으로 나타났으며, 오미자 혼합비율이 높은 추출물에서 $5.85 \%$ 로 가장 높게 나타났다. Jeong 등(26)은 후숙 온도에 따른 오미 자의 이화학적 특성 변화에서 수확 시 오미자의 $\mathrm{pH}$ 는 2.81 이었고 산도는 $5.59 \%$ 라고 하였으며, $\mathrm{Kim}$ 등(27)은 오미자 의 산도는 $4.9 \%$ 라고 보고하였는데 본 연구에서는 산도가 높은 오미자의 영향을 받아 오미자의 혼합비율이 높은 추출 물의 $\mathrm{pH}$ 가 가장 낮게 나타났으며 산도는 높게 분석되었다.

Table 2. $\mathrm{pH}$, sugar content, and acidity of medicinal fruit mixture

\begin{tabular}{cccc}
\hline Sample $^{1)}$ & $\mathrm{pH}$ & $\begin{array}{c}\text { Sugar content } \\
\left({ }^{\circ} \text { Brix }\right)\end{array}$ & Acidity (\%) \\
\hline MS & $3.37 \pm 0.01^{\mathrm{c} 2)}$ & $4.00 \pm 0.00^{\mathrm{d}}$ & $5.18 \pm 0.39^{\mathrm{b}}$ \\
M1 & $3.32 \pm 0.01^{\mathrm{d}}$ & $4.07 \pm 0.12^{\mathrm{c}}$ & $4.80 \pm 0.26^{\mathrm{c}}$ \\
M2 & $3.22 \pm 0.02^{\mathrm{e}}$ & $4.20 \pm 0.00^{\mathrm{a}}$ & $5.85 \pm 0.00^{\mathrm{a}}$ \\
M3 & $3.52 \pm 0.02^{\mathrm{a}}$ & $3.20 \pm 0.20^{\mathrm{e}}$ & $3.60 \pm 0.00^{\mathrm{e}}$ \\
M4 & $3.49 \pm 0.02^{\mathrm{b}}$ & $4.10 \pm 0.00^{\mathrm{b}}$ & $4.05 \pm 0.00^{\mathrm{d}}$ \\
\hline
\end{tabular}

${ }^{1}$ MS, A mixture of same ratio (Corni fructus : Schizandra chinensis : Rubus coreanus Miquel : Lycii folium $=1.25: 1.25: 1.25: 1.25)$; M1, A mixture of different ratio (Corni fructus : Schizandra chinensis : Rubus coreanus Miquel : Lycii folium $=2: 1: 1: 1) ;$ M2, A mixture of different ratio (Corni fructus : Schizandra chinensis : Rubus coreanus Miquel : Lycii folium $=1: 2: 1: 1)$; M3, A mixture of different ratio (Corni fructus : Schizandra chinensis : Rubus coreanus Miquel

: Lycii folium = 1:1:2:1); M4, A mixture of different ratio (Corni fructus Schizandra chinensis : Rubus coreanus Miquel : Lycii folium $=1: 1: 1: 2)$.

${ }^{2)}$ Means $\pm \mathrm{SD}(\mathrm{n}=3)$ with different letters $(\mathrm{a}-\mathrm{e})$ above bars are significantly different by Duncan's multiple range test $(\mathrm{p}<0.05)$.

\section{추출수율, 총 폴리페놀함량, 총 플라보노이드함량 및 총 당함량}

약용열매 혼합 열수 추출물의 추출수율, 총 폴리페놀, 총 플라보노이드 및 총 당 함량은 Table 3 과 같다. 추출수율 은 각각의 추출물에서 유의적인 차이를 나타내었는데, M2(42.33\%), M1(40.40\%), MS(36.03\%), M4(35.90\%) 및 $\mathrm{M} 3(32.53 \%)$ 순으로 오미자 혼합비율이 높은 추출물이 가 장 높았고 복분자 혼합비율이 높은 추출물에서 가장 낮았 다. 총 폴리페놀 및 플라보노이드 함량은 $\mathrm{M} 3$ 이 각각 14.54 $\mathrm{g} / 100 \mathrm{~g}$ 및 $5.65 \mathrm{~g} / 100 \mathrm{~g}$ 으로 가장 많이 함유되어 있었으며 다른 구간에 비해 복분자 혼합비율이 높은 추출물에서 페놀 성물질의 함량이 가장 우수함을 확인하였다. 복분자 혼합
비율이 높은 추출물의 총 폴리페놀 함량은 $14.54 \mathrm{~g} / 100 \mathrm{~g}$ 으 로 가장 높게 나타났으며, 총 폴리페놀 함량이 가장 낮게 나타난 오미자 혼합비율이 높은 추출물보다 약 2 배 정도 높게 나타났다. 오미자와 배를 이용한 혼합발효주 제조 방 법에 대한 연구에서 오미자 및 복분자 발효액의 총 페놀 함량은 각각 $1,017.0 \mathrm{mg} / \mathrm{L}$ 및 $3,139.0 \mathrm{mg} / \mathrm{L}$ 로 복분자 발효액 은 오미자 발효액에 비하여 3배 정도 높게 함유하고 있다고 보고하였다(28). 총 플라보노이드함량은 $\mathrm{M} 3$ 에서 5.65 $\mathrm{g} / 100 \mathrm{~g}$ 으로 가장 높게 나타났으나, 다른 추출물은 4.00 $4.66 \mathrm{~g} / 100 \mathrm{~g}$ 으로 유사하게 나타났다. 이러한 페놀성 화합물 은 식물계에 널리 분포되어 있는 2 차 대사산물의 하나로서 다양한 구조와 분자량을 가지며 플라보노이드와 탄닌이 주성 분이다. 이들은 phenolic hydroxyl $(\mathrm{OH})$ 기를 갖기 때문 에 단백질 및 기타 거대 분자들과 쉽게 결합하며, 항산화 및 항암 등의 다양한 생리활성을 가진다. 축합형 탄닌은 녹차를 비롯한 찻잎의 주된 폴리페놀 성분으로 알려져 있으 며 충치 예방, 고혈압 억제, 항에이즈, 항암, 항산화 및 미백 효과 등이 보고되어 있다(29). 총 당 함량은 39.30 48.36 $\mathrm{g} / 100 \mathrm{~g}$ 으로 나타났으며, 유의적인 차이를 나타내었다. Lee 등(30)은 총 당 함량은 추출 수율과 유사하게 나타난다고 보고하였는데, 추출수율이 가장 높았던 $\mathrm{M} 2$ 의 총 당 함량이 $48.36 \mathrm{~g} / 100 \mathrm{~g}$ 으로 높게 나타나 유사한 경향을 나타내었다.

Table 3. Yield, total polyphenol, total flavonoid, and total sugar contents of extracts from medicinal fruit mixture

\begin{tabular}{ccccc}
\hline Sample $^{\mathrm{l})}$ & $\begin{array}{c}\text { Yield } \\
\text { (dry basis, \%) }\end{array}$ & $\begin{array}{c}\text { Total phenolic } \\
(\text { TA, g/100 g) }\end{array}$ & $\begin{array}{c}\text { Total } \\
\text { flavonoid } \\
\text { (Rutin, g/100 g) }\end{array}$ & $\begin{array}{c}\text { Total sugar } \\
\text { (Glucose, g/100 g) }\end{array}$ \\
\hline MS & $\left.36.03 \pm 0.30^{\mathrm{c} 2}\right)$ & $9.78 \pm 0.29^{\mathrm{b}}$ & $4.66 \pm 0.04^{\mathrm{b}}$ & $39.30 \pm 0.03^{\mathrm{d}}$ \\
M1 & $40.40 \pm 0.40^{\mathrm{b}}$ & $7.86 \pm 0.28^{\mathrm{c}}$ & $4.14 \pm 0.07^{\mathrm{d}}$ & $41.70 \pm 0.07^{\mathrm{c}}$ \\
M2 & $42.33 \pm 0.33^{\mathrm{a}}$ & $7.29 \pm 0.26^{\mathrm{e}}$ & $4.39 \pm 0.03^{\mathrm{c}}$ & $48.36 \pm 1.32^{\mathrm{a}}$ \\
M3 & $32.53 \pm 0.36^{\mathrm{d}}$ & $14.54 \pm 1.22^{\mathrm{a}}$ & $5.65 \pm 0.22^{\mathrm{a}}$ & $45.13 \pm 0.50^{\mathrm{b}}$ \\
M4 & $35.90 \pm 0.52^{\mathrm{c}}$ & $7.64 \pm 0.37^{\mathrm{d}}$ & $4.00 \pm 0.65^{\mathrm{e}}$ & $41.04 \pm 0.26^{\mathrm{c}}$ \\
\hline
\end{tabular}

${ }^{11}$ MS, A mixture of same ratio (Corni fructus : Schizandra chinensis : Rubus coreanus Miquel : Lycii folium $=1.25: 1.25: 1.25: 1.25$ ); M1, A mixture of different ratio (Corni fructus : Schizandra chinensis : Rubus coreanus Miquel : Lycii folium $=2: 1: 1: 1)$; M2, A mixture of different ratio (Corni fructus : Schizandra chinensis : Rubus coreanus Miquel: Lycii folium = $1: 2: 1: 1$ ); M3, A mixture of different ratio (Corni fructus : Schizandra chinensis : Rubus coreanus Miquel Lycii folium = 1:1:2:1); M4, A mixture of different ratio (Corni fructus Schizandra chinensis : Rubus coreanus Miquel : Lycii folium $=1: 1: 1: 2)$.

${ }^{2}$ Means \pm SD ( $\mathrm{n}=3$ ) with different letters (a-e) above bars are significantly different by Duncan's multiple range test $(\mathrm{p}<0.05)$.

\section{DPPH 및 ABTS radical 소거활성}

Radical은 불안정하여 세포 구성 성분들과 쉽게 반응하 여 비선택적이고 비가역적인 손상을 일으킨다. 보라빛을 나타내는 DPPH radical은 비교적 안정한 화합물로 항산화 제와의 반응에 의해 radical 활성을 검정하는데 사용된다 (31). 추출물의 DPPH 및 $\mathrm{ABTS}$ radical 소거활성은 Fig. 1 과 같다. DPPH radical 소거활성은 복분자 혼합비율이 높은 
$\mathrm{M} 3$ 이 250 1,000 $\mu \mathrm{g} / \mathrm{mL}$ 농도에서 25.80 86.09\%로 가장 높 은 활성을 나타내었으며, 양성대조군으로 사용한 ascorbic acid는 $100 \mu \mathrm{g} / \mathrm{mL}$ 농도에서 $66.65 \%$ 의 항산화 활성을 나타 내었다. 다른 추출물은 $250 \sim 1,000 \mu \mathrm{g} / \mathrm{mL}$ 농도에서 $\mathrm{MS}$ 17.89 65.69\%, M1 14.65 57.63\%, M2 12.89 45.94\% 및 M4 $11.69 \sim 6.16 \%$ 순으로 약용열매 혼합비율이 동일한 MS의 $\mathrm{DPPH}$ radical 소거활성이 M3 다음으로 높았으며, 모든 시 료에서 농도 의존적으로 증가하였다. Lee 등(32)은 추출온 도에 따른 산수유 추출물의 DPPH radical 소거활성을 조사 한 결과 산수유 추출물의 농도가 증가할수록 DPPH radical 소거 활성이 유의하게 증가하였으며, Lee 등(33)은 복분자 메탄올 추출물의 DPPH radical 소거 활성이 $50 \mu \mathrm{g} / \mathrm{mL}$ 농도 에서는 $94.90 \pm 0.68 \%$ 이며, $100 \mu \mathrm{g} / \mathrm{mL}$ 농도에서는 $95.93 \pm$ $0.81 \%$ 로 $50 \mu \mathrm{g} / \mathrm{mL}$ 농도 이상에서 농도 의존적으로 유의 하게 높은 항산화 효과가 있는 것으로 나타났다고 보고하 였다.

(A)

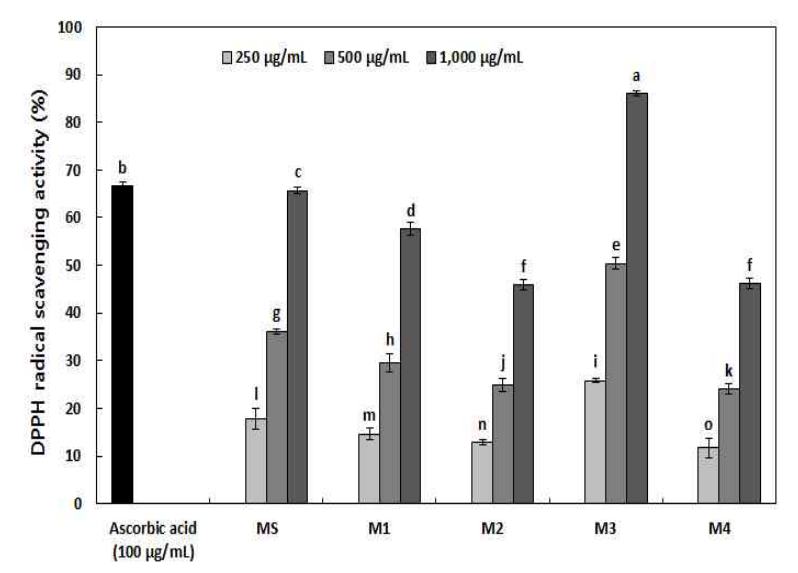

(B)

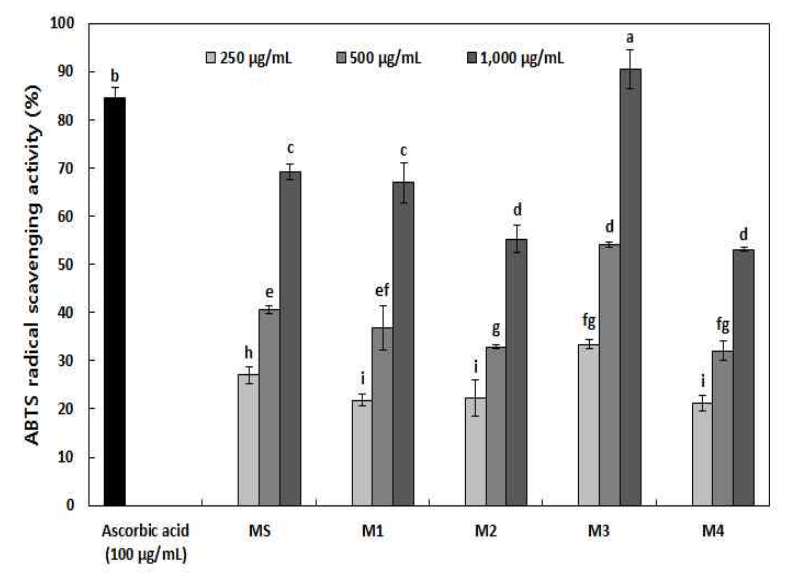

Fig. 1. DPPH (A) and ABTS (B) radical scavenging activity of extracts from medicinal fruit mixture.

Means \pm SD ( $\mathrm{n}=3$ ) with different letters ( $\mathrm{a}-0)$ above bars are significantly different by Duncan's multiple range test $(\mathrm{p}<0.05)$.
ABTS radical 소거활성은 모든 추출물에서 농도가 증가 함에 따라 소거 활성이 증가하였으며, 특히 250 1,000 $\mu \mathrm{g} / \mathrm{mL}$ 농도에서 $\mathrm{M} 3$ 은 33.43 90.49\%로 가장 높은 활성을 나타내어 DPPH radical 소거활성과 유사한 경향을 나타내 었다. $1,000 \mu \mathrm{g} / \mathrm{mL}$ 농도에서 $\mathrm{M} 3$ 은 $90.49 \%$ 로 유의적으로 높은 활성을 나타내었으며, $\mathrm{MS} \quad 27.07 \sim 69.22 \%, \mathrm{M} 1$ 21.78 66.91\%, M2 22.28 55.21\% 및 M4 21.16 53.12\% 순 으로 나타나 DPPH radical 소거활성과 유사하게 나타났다. Jun 등(34)은 복분자와 오디의 ABTS radical 소거활성을 조사한 결과 $60 \%$ acetone 추출물은 시료의 농도가 증가할 수록 항산화 활성이 증가하여 농도 의존적인 특성을 보였다 고 보고하였다. 모든 추출물에서 ABTS radical 소거활성이 $\mathrm{DPPH}$ radical 소거활성에 비하여 높은 활성을 나타내었는 데, 이는 다수의 연구에서 ABTS radical 소거활성의 경우 DPPH radical 소거활성보다 수소 공여 항산화 물질과 chain breaking 항산화 물질을 모두 측정할 수 있어 더 높은 활성을 나타낸다고 보고하여 본 연구 결과와 일치하였다 $(22,35)$.

\section{FRAP 및 환원력}

FRAP에서는 추출물에 존재하는 항산화 물질이 산화제 로 작용해 산화-환원 반응에 사용되며, Ferric 2,4,6-tripyridylS-triazine의 $\left[\mathrm{Fe}(\mathrm{III})-(\mathrm{TPTZ})_{2}\right]^{2+}$ 화합물은 산화-환원 반응에 의해 파란색을 띠는 ferrous complex $\left[\mathrm{Fe}(\mathrm{III})-(\mathrm{TPTZ})_{2}\right]^{3+}$ 로 변한다(36). 측정된 파란색의 강도는 추출물의 항산화 물질 양과 관련이 있다고 보고되고 있다(37). 약용열매 혼합비율 에 따른 추출물의 FRAP 및 환원력은 Fig. 2와 같다. FRAP는 $\mathrm{M} 3$ 이 250 1,000 $\mu \mathrm{g} / \mathrm{mL}$ 농도에서 0.36 0.86 $\mu \mathrm{M}$ 로 가장 높 은 활성을 나타내었으며, MS, M1, M2 및 M4는 각각

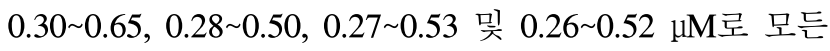
시료에서 농도 의존적으로 FRAP가 증가됨을 확인하였다. Hwang 등(38)은 경북약용작물(홍화자, 향부자, 형개, 위유 및 작약)의 $\mathrm{FRAP}$ 를 조사한 결과 5가지 약용작물 중 $\mathrm{FRAP}$ 값은 홍화자 $1,914.95 \pm 2.11 \mu \mathrm{M} \mathrm{Fe} / \mathrm{mg}$ 로 가장 높은 FRAP 활성을 나타냈으며, 총 페놀 및 플라보노이드 함량과 비교 했을 때 5 가지 약용식물 중 홍화자 추출물에서 모두 높은 함량으로 동일한 결과를 확인할 수 있다고 보고하였다.

환원력은 reduction의 항산화 반응에서 hydrogen atom을 제공함으로써 자유라디칼 연쇄를 변환시키며, reduction은 또한 과산화의 일정한 전구물질과 반응하여 과산화의 형성 을 방해한다. Flavonol 물질은 이 안정된 생성물로 그들을 전화시키기 위해 자유라디칼과 반응하거나 전자를 제공함 으로써 reduction과 같은 유사한 형태에서 반응하고 자유라 디칼 연쇄반응을 끝낸다고 보고되고 있다(39). 항산화 작용 의 여러 가지 기작 중에서 활성 산소종 및 유리기에 전자를 공여하는 능력이 환원력이므로 이를 측정하여 항산화 활성 을 검정하는 수단으로 이용할 수 있으며, 환원력이 강할수 록 녹색에 가깝게 발색되므로 항산화 활성이 큰 물질일수록 
높은 흡광도 값을 나타낸다(40). 약용열매 혼합비율에 따른 추출물의 환원력은 모든 시료가 $250 ~ 1,000 \mu \mathrm{g} / \mathrm{mL}$ 농도에서 0.21 0.96으로 높은 활성을 나타내었으며, 농도 의존적으 로 증가하였다. 특히 $\mathrm{M} 3$ 의 $1,000 \mathrm{\mu g} / \mathrm{mL}$ 농도에서 0.96 으로 나타났으며, 양성대조군으로 사용한 ascorbic acid는 100 $\mu \mathrm{g} / \mathrm{mL}$ 농도에서 0.82 의 활성을 나타내었다. 다른 추출물은 $1,000 \mathrm{\mu g} / \mathrm{mL}$ 농도에서 MS 0.27 0.80, M1 0.23 0.70, M4 0.22 0.66 및 M2 0.21 0.59 순으로 나타났다. 총 폴리페놀 및 플라보노이드 함량이 높은 $\mathrm{M} 3$ 에서 다른 추출물에 비해 FRAP와 같이 환원력 또한 활성이 높음을 확인하였으며, 이는 식물체 내에 있는 다양한 항산화 성분들이 그들의 특성에 따라 다른 항산화 활성을 나타낼 수 있기 때문으로 생각된다(41). 따라서, 약용열매 혼합 열수 추출물의 항산 화 활성을 분석한 결과, 복분자 혼합비율이 높은 추출물에 서 항산화활성이 우수함을 확인하였다.

(A)

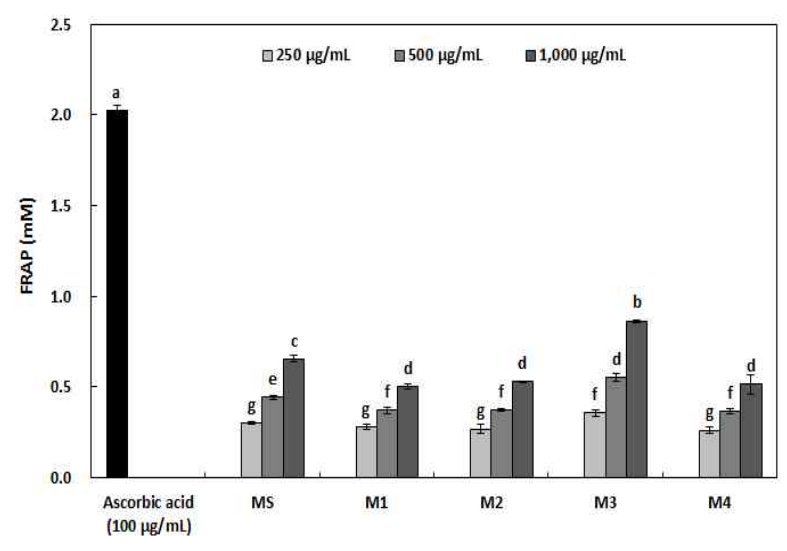

(B)

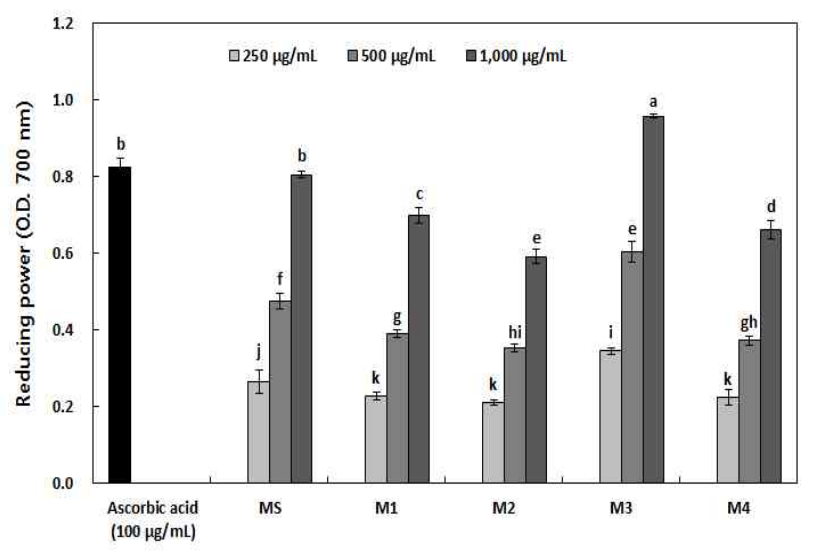

Fig. 2. FRAP (ferric reducing antioxidant power) (A) and reducing power (B) of extracts from medicinal fruit mixture.

Means \pm SD $(n=3)$ with different letters $(a-k)$ above bars are significantly different by Duncan's multiple range test $(\mathrm{p}<0.05)$.

\section{요 약}

본 연구에서는 다양한 생리활성을 가진다고 알려져 있는 약용열매인 산수유, 오미자, 복분자 및 구기자 4 종의 기능 성식품 소재로 활용하고자 혼합비율별로 추출한 열수 추출 물의 이화학적 특성 및 항산화 활성을 조사하였다. 약용열 매 혼합비율에 따른 열수 추출물의 $\mathrm{pH}$ 는 3.22 3.52로 산성 을 나타내었으며, 당도는 $\mathrm{M} 3$ 이 $3.20{ }^{\circ} \mathrm{Brix}$ 로 다른 시료에 비해 낮았고 산도는 $3.60 ~ 5.85 \%$ 으로 오미자 혼합비율이 높은 구간에서 $5.85 \%$ 로 가장 높게 나타났다. 추출수율은 $\mathrm{M} 2, \mathrm{M} 1, \mathrm{MS}, \mathrm{M} 4$ 및 M3 순으로 나타났으며, 총 폴리페놀 및 플라보노이드 함량은 각각 14.54 및 $5.65 \mathrm{~g} / 100 \mathrm{~g}$ 으로 복분자 혼합비율이 높은 추출물인 $\mathrm{M} 3$ 에서 가장 높은 값을 나타내었다. DPPH 및 ABTS radical 소거활성은 M3이 $250 \sim 1,000 \mathrm{\mu g} / \mathrm{mL}$ 농도에서 25.80 86.09\% 및 33.43 90.49\% 로 가장 높게 나타났다. FRAP 및 환원력은 M3가 250 1,000 $\mu \mathrm{g} / \mathrm{mL}$ 농도에서 각각 0.36 0.86 $\mu \mathrm{M}$ 및 0.21 0.96으로 가장 우수하였으며, 모든 혼합 열수 추출물에서 농도 의존적으 로 증가하였다.

\section{감사의 글}

본 연구는 산업통상자원부에서 지원하는 2015년도 지역 주력산업육성(R\&D) 기술개발사업(No.R0003691)의 연구 수행으로 인한 결과물임을 밝힙니다.

\section{References}

1. Lodovici M, Guglielmi F, Meoni M, Dolara P (2001) Effect of natural phenolic acids on DNA oxidation in vitro. Food Chem Toxicol, 39, 1205-1210

2. Kim SH, Choi HJ, Oh HT, Chung MJ, Cui CB, Ham SS (2008) Cytoprotective effect by antioxidant activity of Codonopsis lanceolata and Platycodon grandiflorum ethylacetate fraction in human HepG2 cells. Korean $\mathbf{J}$ Food Sci Techenol, 40, 696-701

3. Park SY, Kim JW (1992) Screening and isolation of the antitumor agents from medicinal plants ( I ). Korean J Pharmacogn, 23, 264-267

4. Stella SP, Ferrarezi AC, dos Santos KO, Monteriro M (2011) Antioxidant activity of commercial ready-to-drink orange juice and nectar. J Food Sci, 76, 392-397

5. Yang MS, Ha YL, Nam SH, Choi SU, Hang DS (1995) Screening of domestic plants with antibacterial activity. J Korean Soc Agric Chem Biothchnol, 38, 584-589 
6. Kim KD (2004) Research of oriental medicine plant on antioxidation and ultraviolet tays absorption. J Korean Soc Cosm, 10, 145-153

7. Han SH, An TJ, Kim YI, Hur M, Lee YS (2013) Health keeper, medical uses of fruits. RDA interrobang, 107, 10-19

8. Lee SO, Lee HJ, Yu MH, Im HG, Lee IS (2005) Total polyphenol contents and antioxidant activities of methanol extracts from vegetables produced in Ulung island. Korean J Food Sci Technol, 37, 233-240

9. Chung SR, Jeune KH, Park SY, Jang SJ (1993) Toxicity lectins constituents from the seed of Cornus officinalis. Korean J Pharmacogn, 24, 177-182

10. Lee JY (1981) Iridoid glycosides of Cornus officinalis. MS Thesis. Seoul National University, Seoul, Korea

11. Seo KI, Lee SW, Yang KH (1999) Antimicrobial and antioxidantive activities of Corni fructus extracts. Korean J Postharvest Sci Technol, 6, 99-103

12. Lee JS, Lee MG, Lee SW (1989) A study on the general components and minerals in parts of Omija (Schizandra chinensis Baillon). Kor J Dietary Culture, 4, 173-176

13. Oh SL, Kim SS, Min BY, Chung DH (1990) Composition of free sugars amino acids non volatile organic acids and tannins in the extracts of $L$ chinensis $M, A$ acutiloba $K$, $S$. chinensis $B$ and $A$ sessiliflorum $S$. Korean J Food Sci Technol, 22, 76-81

14. Jeon YH, Choi SW, Kim MR (2009) Antimutagenic and cytotoxic activity of ethanol and water extracts from Rubus coreanus. Korean J Food Cookery Sci, 25, 379-386

15. Kim S, Kim CK, Lee KS, Hwang H, Jeoung D, Choe J, Won MH, Lee H, Ha KS, Kwon YG, Kim YM (2013) Aqueous extract of unripe Rubus coreanus fruit attenuates atherosclerosis by improving blood lopid profile and inhibiting NF-kB activatiom via phase $\Pi$ gene expression. J Ethnopharmacol, 146, 515-524

16. Park MC, Kim KJ, Lee HS, Jo EH (2007) Attenuation of airway hyperreactivity (AHR) and inflammation by water extract of Rubus coreanus Miq. (WRCM). J Korean Orient Med Ophthalmol Otolaryngol Dermato, 20, 177-194

17. Kim JH, Kim JS (2014) Effects of Lycii fructus and Lycii folium extracts on osteoporosis in ovariectomized rats. J Korean Soc Food Sci Nutr, 43, 24-29

18. Singleton VL, Rossi JA (1965) Colorimetry of total phenolics with phosphomolybdic-phosphotungstic acid reagents. AM J Enol Viticult, 16, 144-158

19. Jia Z, Tang M, Wu J (1999) The determination of flavonoid contents in mulberry and their scavenging effect on superoxide radicals. Food Chem, 64, 555-559

20. Dubois M, Gillers KA, Hamiton JK, Rebers PA, Smith F (1956) Colorimetric method for determination of sugar and related substance. J Anal Chem, 28, 350-356

21. Blois MS (1958) Antioxidant determinations by the use of a stable free radical. Nature, 181, 1199-1200

22. RE R, Pellegrini N, Proteggente A, Pannala A, Yang M, Rice-Evans C (1999) Antioxidant activity applying an improved ABTS radical cation decolorization assay. Free Radic Biol Med, 26, 1231-1237

23. Benzie IF, Strain JJ (1996) The ferric reducing ability of plasma (FRAP) as a measure of "antioxidant power" the FRAP assay. Anal Biochem, 239, 70-76

24. Oyaizu M (1986) Studies on products of browning reaction-antioxidative activities of products of browning reaction prepared from glucosamine. Jpn J Nutr, 44, 307-315

25. Lee YJ, Kim JC, Hwang KT, Kim DH, Jung CM (2013) Quality characteristics of black raspberry wine fermented with different yeasts. J Korean Soc Food Sci Nutr, 42, 784-791

26. Jeong PH, Kim YS, Shin DH (2006) Changes of physicochemical haracteristics of Schizandra chinensis during postharvest ripening at various temperatures. Korean J Food Sci Technol, 38, 469-474

27. Kim KI, Nam JH, Kwon TW (1973) On the proximate composition, organic acids and anthocyanins of Omija, Schizandra chinensis Baillon. Korean J Food Sci Technol, 5, 178-182

28. Jeong ST, Kong MH, Yeo SW, Choi JH, Choi HS, Han GJ (2010) Studies on the mixture wine processing using omija and pear. J East Asian Soc Dietary Life, 20, 896-902

29. Yoshizawa S, Horiuchi T, Yoshida T, Okuda T (1987) Antitumor promoting activity of (-)-epigallocatechin gallate, the main constituent of tannin in green rea. Phytotherapy Res, 1, 44-47

30. Lee GY, Son YJ, Jeon YH, Kang HJ, Hwang IK (2015) Changes in the physicochemical properties and sensory characteristics of Burdock (Arctium lappa) during repeated steaming and drying procedures. Korean J Food Sci Thchnol, 47, 336-344

31. Bondet V, Brand-Williams W, Berset C (1997) Kinetics and mechanisms of antioxidant activity using the DPPH free radical method. Lebensm Wiss Technol, 30, 609-615

32. Lee MH, Kim JM, Park EJ (2011) Antioxidant and 
antigenotoxic effects of sansuyu fruit (Corni fructus) extracted with water at different temperatures. J Korean Soc Food Sci Nutr, 40, 149-155

33. Lee IS, Kim YM, Kim HT (2015) The effects of anti-oxidant and phototoxic inhibitory activity of Rubus coreanus Fruits. J Korean Med Ophthalmol Otolaryngol Dermatol, 28, 1-10

34. Jun HI, Kim YA, Kim YS (2014) Antioxidant activities of Rubus coreanus Miquel and Morus alba L. Fruits. J Korean Soc Food Sci Nutr, 43, 381-388

35. Li H, Choi YM, Lee JS, Park JS, Yeon KS, Han CS (2007) Drying and antioxidant characteristics of the shiitake (Lentinus edodes) mushroom in a conveyer type far-infrared dryer. J Korean Soc Food Sci Nutr, 36, 250-254

36. Loganayaki N, Suganya N, Manian S (2012) Evaluation of edible flowers of agathi (Sesbania grandiflora L. Fabaceae) for in vivo anti-inflammatory and analgesic, and in vitro antioxidant potential. Food Sci Biotechnol, 21, 509-517

37. Jeong CH, Bae YI, Prak SJ, Lee SK, Hur SJ (2012) Antioxidant activity of aqueous extracts from three cultivars of guava leaf. Food Sci Biotechnol, 21, $1557-1563$

38. Hwang EY, Kim DH, Kim HJ, Hwang JY, Park TS, Lee IS, Son JH (2011) Antioxidant activities and nitric oxide production of medicine plants in gyeongsangbukdo (Carthamus tinctorius seed, Cyperus rotundus, Schizonepeta tenuifolia, Polygonatum odoratum var. pluriflorum, Paeonia lactiflora). J Appl Biol Chem, 54, 171-177

39. Wettasinghe M, Shahdi F (1999) Antioxidant and free radical-scavenging properties of ethanolic extracts of defatted borage(Borago officinalis L.) seeds. Food Chem, 67, 399-414

40. Yim MH, Hong TG, Lee JH (2006) Antioxidant and antimicrobial activities of fermentation and ethanol extracts of pine needles (Pinus densiflora). Food Science and Biotechnology, 15, 582-588

41. Moure A, Cruz JM, Franco D, Domínguez JM, Sineiro J, Domínguez H, José Núñez M, Parajó JC (2001) Natural antioxidants from residual sources. Food Chem, 72, 145-171 